\title{
LANGUAGE AS ETHNIC VALUE (ON THE CHECHEN LANGUAGE EXAMPLE)
}

\author{
C) Raisa S. Ilyasova \\ Chechen state university. Grozny, Russian Federation \\ science-almanac@mail.ru
}

It is considered the development of the Chechen language in the context of globalization. The ways of expanding the sociolinguistic functions of the language are analyzed. The Chechen language along with other languages of Russian peoples, as is known, is classified as a minority. But there is a reason to believe that most of the signs of extinction of languages are not applicable to the Chechen language: the number of Chechens is 1.5 million, the concise living of the population in rural areas (more than $70 \%$ ), the mono-nationality of the republic, language learning in kindergartens, school, university, theater, a highly developed theater and stage, mass publication of newspapers, magazines, art works, the translation of films into their native language, creation of original Chechen films. In recent decades, the problem of expanding the use of the written form of the Chechen language has been actualized. Especially in this regard, it is important to address the problem of the transfer to the Chechen language of primary school education in conditions of a mono-ethnic population of the republic with a population of one and a half million people. This problem was widely discussed ten years ago, but now it is raised more rarely. There is not much hope that it will be resolved in favor of the Chechen language (and in favor of the languages of the peoples of Russia as a whole in the country) according to the steps taken by the State Duma and federal agencies to restrict the functions of the languages of the peoples of the Russian Federation, even the languages of titular nations in the corresponding national State formations on the territory of the federal Russian state. Especially indicative in this respect is the draft law on the study of native languages on a voluntary basis, and in fact - the assignment to the relevant subjects - the native language and literature of optional status in educational standards and in curricula.

However, this has not happened yet and there is a weak hope that ethnophobic forces will not prevail and the tendency of a balanced national-Russian bilingualism and national and cultural diversity in our country will develop further with the preservation of the conditions for the preservation and development that have developed over the past two to three decades native languages of non-Russian ethnoses of Russia. In the Chechen Republic, this trend manifested itself, for example, that over the past 20-25 years, the oral form of the use of the Chechen language has significantly expanded its base: in contrast to the Soviet period, at the level of government, ministries, departments, and district administrations, etc.

Key words: ethnic language, Chechen language, minority language, social status of the Chechen language, interaction of languages, language situation.

\section{[P.C. Ильясова Язык как этническая ценность (на примере чеченского языка)]}

Статья посвящена развитию чеченского языка в условиях глобализации. Анализируются пути расширения социолингвистических функций языка. Чеченский язык наряду с большинством других языков народов России, как известно, относят к числу миноритарных. Но есть основания считать, что к чеченскому языку не применимы большинство признаков вымирания языков: численность чеченцев 1,5 млн., компактное проживание населения в сельской местности (более $70 \%$ ), мононациональность республики, изучение языка в детсадах, школе, вузе, работа национального театра, сильно развитый театр и эстрада, массовое издание газет, журналов, художественных произведений, перевод фильмов на родной язык, создание оригинальных чеченских фрильмов.

В последние десятилетия актуализировалась проблема расширения использования письменной формы чеченского языка. Особенно в этом плане важно решение проблемы перевода на чеченский язык обучения начальной школы в условиях мононационального состава населения республики с численностью в полтора миллиона человек. Эта проблема широко обсуждалась еще десять лет назад, но сейчас ее поднимают все реже. Предпринимаемые Госдумой и федеральными ведомствами шаги, направленные на ограничение функций языков народов РФ, даже языков титульных наций в соответствующих национально-государственных образованиях на территории федеративного Российского государства не вселяют надежду, что данная проблема будет решена в пользу чеченского языка (и в пользу языков народов России в целом в стране). Особенно показателен в 
этом отношении законопроект об изучении родных языков на добровольной основе, а фактически отведения соответствующим предметам - родному языку и литературе факультативного статуса в образовательных стандартах и в учебных планах. Однако этого еще не случилось и есть надежда, что этнофобские силы не возьмут верх и тенденция сбалансированного национально-русского двуязычия, национально-культурного многообразия в нашей стране будет развиваться дальше с сохранением сложившихся за последние два-три десятилетия условий для сохранения и развития родных языков нерусских этносов России. В Чеченской Республике эта тенденция проявила себя в том, например, что за последние 20-25 лет устная форма применения чеченского языка значительно расширила свою базу: в отличие от советского периода в настоящее время на чеченском языке ведутся совещания на уровне правительства, министерств, департаментов, и администраций районов и т.д.

Ключевые слова: этнический язык, чеченский язык, миноритарный язык, социальный статус чеченского языка, взаимовлияние языков, языковая ситуация.

Raisa S. llyasova - candidate of philology, associate professor. Chechen state university. Grozny, Russian Federation.

Ильясова Раиса Сайтхасановна - кандидат фрилологических наук, доцент. Чеченский государственный университет. г. Грозный, Россия.

In the conditions of globalisation minority languages are greatly influenced by ethnic and world languages. Mass Media, Internet, cable multichannel television, cellular communication and almost house-to-house telephonisation, the processes of globalization have changed the environment for the existence and functioning of the languages of small nations. In this regard the Chechen language is not an exclusion as it experiences fundamental changes under the influence of Russian language. The sphere of use of the Chechen language is often restricted to domestic communication. As a result the bearers of the language lose whole groups of lexical units, such as names of animals, plants, production terms and even such part of speech as numerals $[13,15]$. Recent researches show that the material of Nakh languages can be of invaluable help in the comparativehistorical study of Indo-European and Asiatic languages. To prove it, several EnglishChechen dictionary correspondences are enough, for example: English. bull. - bula 'wild bull, bison', engl. steer 'bull' - chech. stu 'bull', genus. stera; Eng. stirk 'goby' - Chech. stargh 'goby', engl. stag 'the buck; bachelor '- Chechen. stag 'man', saj 'deer' (<sag), dr.Eng. buck 'goat' - the Chech. buož 'goat' (<buog), English ass 'donkey' (<al-English asse) - Chechnya. esa 'calf' (<as-ch. asi), other-English. wer 'man' (Latin vir) - Chechen. vir 'donkey' [2]. Among the Semito-Nakh parallels one can note, in particular, the following: semit. bar 'son'. bar // ber 'child', semit. mar'- 'man, man' - Chechen. mar 'husband', semit. berit 'union' - Chechen. bart 'union', semit. jam 'the sea' - the Chechen. 'Am' lake ', semit. 'Ajn' the eye; source '- the Chechen. 'In' the ravine, the abyss' [2, 3].

The Chechen language is known to be classified as a minority language along with the majority of other languages of Russian nations $[1 ; 5 ; 6 ; 8]$. But there are reasons to believe that the majority of signs of extinction of languages can not be applied to the Chechen language: the number of Chechens is 1.5 million, the compact living of the population in rural areas (more than $70 \%$ ), the mono-nationality of the republic, language learning in kindergartens, school, university, work of the national theater, the highly developed theater and variety, the mass publication of newspapers, magazines, art works, the translation of films into the native language, the creation of original Chechen films and cartoons. In a number of the articles A.I. Khalidov indicates on the prematurity of considering of the Chechen language as "dying" and the conventionality of applying to it the concept of "minority" [13; 14]. Z.M. Gabunia and R.G. Tirado [5] believe that the com- 
pact living of the population, its small migration, life in the countryside and the preservation of endogamy contribute to the preservation and development of the language.

The ecology of the Chechen language in Grozny still leaves a lot to be desired. All signs, names of streets, avenues, districts, cultural and science institutions, publishing houses, etc. are designed in Russian. In this regard it is especially necessary to distinguish onymy - the names of streets, squares, etc., such a variety of onyms as ergons names of shopping and entertainment centers, etc. So, in Grozny there are streets named after Sergei Lazo, Patrice Lumumba, Rosa Luxemburg, etc. - without names of national heroes, scientists, poets, writers, statesmen: Beibulat Taimiev, Zelimkhan Kharachoevsky, Yunus Chasariev, the founder of Caucasian linguistics P. K. Uslar. When giving names to companies, shopping and entertainment points, their owners prefer not only non-Chechen, but even non-Russian names: Grozny City, Yakuza, Wasabi, Paradise, Benodent, Beeline, etc. It is clear that such names enter our life not only in Grozny and not only in the Chechen Republic but nevertheless in a republic in which the Chechens still occupy more than $90 \%$ of the population structure we should expect a national and linguistic diversity of signboards and names with the predominance executed in the Chechen language. It should be noted that more attention to the Chechen language is paid in the design of the names of state and municipal institutions but here is another problem: in the names of institutions which are as a rule cripples from Russian names, translation mistakes and spelling mistakes are often found - spelling and grammatical. So, for example, the name of the Chechen State Drama Theater named after $\mathrm{H}$. Nuradilov on the pediment of the building is given as "Nokhchin kooman theater" ("Chechen National Theater"). In Grozny, there are a lot of institutions that are the offices of various "committees ... over the Chechen Republic" and all of them in Chechen sound like "Nokhchijen Republicar Urhalla" although correctly - "Nokhchijen Republicahul Urhalla".

In the terminology of modern Chechen language there are two opposite tendencies. The first, the most powerful, is a broad and massive flow of borrowings from the Russian language and through Russian from English. The Russian language helps enrich the vocabulary of the ethnic languages of the peoples of the country. These languages widely borrow technical terms, terms of computer technology and informatics: site, file, flashcard, hard disk, driver, server, scanner, byte, kilobyte, megabyte, macros, mouse, display, processor, printer, fax, the Internet. In addition to direct borrowing from the Russian language national languages also actively use the word-formative and semantic traces of Russian words. Thus, with the help of the suffixoid- йо̄за -writing, -gram, in the Chechen language, the derivational clichees глагол-йо̄за / glagolitsa, кирилл-йо̄за Cyrillic, латин-йо̄за Latin; зайлайоза cuneiform, куьйгайоза manuscript, зурмайоза gramophone; дегайоза cardiogram, ойлайоза ideogram, ренгенйоза radiograph, суртйоза pictograph, m/улайоза petroglyphs, чуртйоза epitaph, кадамйоза obituary [1, p. 46], and with the help of the suffixoid -аьзни "-itsa, -essa", semantic tracings of the lineage of the Snow Maiden are formed in the Chechen language, хи-аьзни mermaids [7, р. 537], кема-аьзни stewardess, кино-аьзни а movie actress movie actress, a movie star, куцаьзни model, сурm-аьзни model [2, p. 34].

The second tendency is the active efforts of specialists of various fields to develop their own terminology of the Chechen language. The desire of philologists to stop the unrestrained flurry of Russian borrowings, which destroys the structure and identity of the language, dictates the practice of replacing Russian teaching terms - sentence, exercise, participle, gerund, quotes, work, collection, textbook, dictionary Chechen terms, алам, шардам, ардамдош, mlеардамдош, иІоьмалгийн къовларш, говзар, гулар, Іамат, гlo-laмат, дошам, де-таьптар. It is believed that in recent decades the problem of expanding the use of the written form of the Chechen language has been actualized. In this regard, it is especially important to address the problem of the transfer to the Chechen 
language of primary school education in conditions of a mono-ethnic population of the republic with a population of one and a half million people. This problem was widely discussed ten years ago but now it is raised more rarely. There is not much hope that it will be resolved in favor of the Chechen language (and in favor of the languages of the peoples of Russia as a whole in the country), judging by the steps taken by the State Duma and federal agencies to restrict the functions of the languages of the peoples of the Russian Federation, even the languages of titular nations in the corresponding nationalState formations on the territory of the federal Russian state. Especially indicative in this respect is the draft law on the study of native languages on a voluntary basis, and in fact the assignment to the relevant subjects, the native language and literature, of optional status in educational standards and in curricula.

A.I. Khalidov believes that the amount of hours allocated by the curriculum to the Chechen language in schools and universities of the republic is clearly insufficient, which naturally cannot but affect the level of knowledge of native language among pupils and students [15, p. 119]. One can imagine what the situation of the Chechen language will be in the general education school and in the educational sphere as a whole after this bill grows into law. In this case, the conditions of functioning and the perspectives of preserving both the Chechen and other languages are likely to change so much that neither A.I. Khalidov, nor someone else will have any reason to doubt that the place of these languages in Atlas of the World's Languages in Danger is among the dying, disappearing.

However this has not happened yet and there is a weak hope that ethnophobic forces will not prevail and the tendency of a balanced national-Russian bilingualism and national and cultural diversity in our country will develop further with the preservation of the conditions for the preservation and development of native languages of non-Russian ethnoses of Russia that have developed over the past two to three decades. In the Chechen Republic, this tendency manifested itself, for example, in the fact that over the past 20-25 years, the oral use of the Chechen language has significantly expanded its base: in contrast to the Soviet period, at the level of government, ministries, departments, and district administrations, etc. According to M.R. Ovkhadov the following tendencies are typical of the language situation of the modern period of the history of the Chechens:

- activation of the use of the Chechen language in the oral sphere - in communication, in social and political life (Friday religious sermons, weekly lectures on the spiritual and moral education of youth, mass events to celebrate the Day of the native language, etc.);

- reduction of the use of Russian spoken language in the oral sphere - in communication, in social and political life (in connection with the decrease in the number of Russian-speaking in the republic) [9, p. 206].

"The activities of the Federal Center for Strengthening the Status of the Russian Language, Languages of the Peoples of the Russian Federation which have been planned since 2015 are very positive. In this respect the "List of Orders of the President of the Russian Federation (Ex 1310 of July 4, 2015) opens a new stage of language construction in our country" [11, p. 148]. A serious step towards increasing the prestige of the Chechen language in society was the announcement by the Decree of the head of the Chechen Republic on April 25 "Day of Mother Language". Annually this day is widely celebrated throughout the country: in every educational institution (school, college, university), events dedicated to the Chechen language are held. The Academy of Sciences, the Ministry of Press, Information and Mass Communications conduct conferences where school teachers, university tutors, writers and journalists who write in the Chechen language are awarded. On this day the numbers of all the republican newspapers, even Russian-language ones, give their pages to the popularization of the Chechen language, publish interviews with leading linguists who talk about their research in the field of Nakh 
linguistics, measures to preserve and further develop the Chechen language and expand its social functions. The role of television in the coverage of the Chechen language day has increased. We should also note the following linguistic tendencies, which require a thorough socio-cultural understanding:

a) the use of Arabic loans in the Chechen language in connection with the construction of mosques, madrassas, schools of Hafiz (not only an increase in the number of borrowings, but also their pronunciation in the Arabic manner: farz, azan, masalan, etc.);

b) the emergence of the phenomenon of Franco-Chechen, German-Chechen, Norwegian-Chechen bilingualism in connection with the immigration of Chechens from the Chechen Republic abroad - as a theoretical and practical task;

c) the discrepancy between the real status of the Chechen language in the republic and its formal state status, which implies an active expansion of its practical, cultural and scientific use.

\section{Лumepamypa}

1. Атаев Б.М. Этнополитические проблемы миноритарных языков Дагестана // Язык, литература, фольклор (книга в честь Юнуса Дешериева). Грозный, 2014.

2. Вагапов А.Д. Словарь неологизмов чеченского языка. Грозный, 2007.

3. Вагапов А.Д. Чеченский язык и финикийский алфавит // Республиканская научно-практическая конференция «Чеченский язык: теория, история, проблемы». Грозный, 2007.

4. Вагапов А.Д. Этимологический словарь чеченского языка. Тбилиси, 2011.

5. Габуния 3.М., Тирадо Р.Г. Миноритарные языки в современном мире. Кавказские языки. М., 2002.

6. Дьячков М.В. Миноритарные языки в полиэтнических (многонациональных) государствах. М., 1996.

7. Карасаев А.Т., Мациев А.Г. Русско-чеченский словарь. М., 1978.

8. Нерознак В.П. Красная книга языков народов России. М., 1994.

9. Овхадов М.P. Национально-языковая политика и развитие чеченско-русского двуязычия. М., 2000.

10. Овхадов М.P. Образовательные и языковые проблемы национальной политики советского периода в Чеченской Республике. Чеченская Республика и чеченцы: история и современность. М.: Наука, 2006.

11. Овхадов М.P., Шамилева Р.Д., Яхъяева А.А. Языковая ситуация в Чеченской Республике. Назрань, 2016.

12. Овхадов М.P., Шамилева Р.Д. Чеченско-русский билингвизм и система имен числительных в чеченском языке. Современные проблемы образования и науки. 2015, № 2-2.

13.Халидов А.И. Обоснованно ли включение чеченского языка в Atlas of the World's Languages in Danger? // Современная наука: актуальные проблемы теории и практики». Серия «Гуманитарные науки». 2014, № 5-6. М., 2014.

14.Халидов А.И. Экология языков Кавказа. Статья первая: Введение. Чеченский язык. // Вестник Академии наук ЧР. № 2 (17), 2012. Грозный, АН ЧР, 2012.

15.Халидов А.И. О необходимости расширения функций чеченского языка в сфрере образования и науки // Язык, литература, фоольклор (книга в честь Юнуса Дешериева). Грозный, 2014. 


\section{References}

1. Atayev B.M. Ethnopolitical problems of minority languages of Dagestan // Language, literature, folklore (book in honor of Yunus Churarev). Grozny, 2014.

2. Vagapov A.D. Dictionary of neologisms of the Chechen language. Grozny, 2007.

3. Vagapov A.D. Chechen language and Phoenician alphabet // Republican scientific-practical conference "Chechen language: theory, history, problems". Grozny, 2007.

4. Vagapov A.D. Etymological dictionary of the Chechen language. Tbilisi, 2011.

5. Gabunia Z.M., Tirado R.G. Minority languages in the modern world. Caucasian languages. M., 2002.

6. Dyachkov M.V. Minority languages in polyethnic (multinational) states. M., 1996.

7. Karasayev A.T., Matziev A.G. Russian-Chechen dictionary. M., 1978.

8. Neroznak V.P. The Red Book of the Languages of the Peoples of Russia. M., 1994.

9. Ovkhadov M.R. National-language policy and the development of ChechenRussian bilingualism. M., 2000.

10. Ovkhadov M.R. Educational and language problems of the national policy of the Soviet period in the Chechen Republic. The Chechen Republic and the Chechens: history and modernity. M., 2006.

11. Ovkhadov M.R., Shamileva R.D., Yakhyaeva A.A. Language situation in the Chechen Republic. Nazran, 2016.

12. Ovkhadov M.R., Shamilev R.D. Chechen-Russian bilingualism and a system of numerals in the Chechen language. Modern problems of education and science. 2015, No. 2-2.

13. Khalidov A.I. Is the inclusion of the Chechen language in Atlas of the World's Languages in Danger justified? // Modern science: actual problems of theory and practice ". Series "Humanities". 2014, No. 5-6. M., 2014.

14. Khalidov A.I. Ecology of the languages of the Caucasus. Article One: Introduction. The Chechen language. // Bulletin of the Academy of Sciences of the Czech Republic. № 2 (17), 2012. Grozny, Academy of Sciences of the CR, 2012.

15. Khalidov A.I. On the need to expand the functions of the Chechen language in the field of education and science // Language, literature, folklore (a book in honor of Yunus Churarev). Grozny, 2014. 